\title{
Mary Wollstonecraft revisited
}

\author{
Ann Curthoys
}

In 1976, I began teaching the first women's studies course at The Australian National University. That course had been fought for and won as a result of student agitation, supported by some academic staff, and I was fortunate enough to be appointed as the first lecturer in women's studies. I was then thirty years old and this was my first lecturing position. When I began teaching, I had little idea how to teach such a course, for I had never been a student in women's studies and my doctoral dissertation had been in another area - a study of race relations in nineteenth-century colonial Australia. What I did know, though, was what I had learnt as an activist in the 1970s women's movement, first in its women's liberation phase and then in its more general incarnation as simply the 'women's movement' or contemporary feminism. And that was in fact quite a lot. The early 1970s women's movement - or at least that part of it I was involved in, in Sydney - was the scene of much reading about women, their situation and their history. At the foundation of this frenzy of reading was a desire to understand why it was that women occupied a subordinate position in society. If their secondary status was not ordained by nature - and that was a fundamental position in 1970s feminism - it had to have some other cause. Our reading in search of a cause or causes extended in all directions and we were much less bound by discipline than we have all since become; we read women's history, philosophy, anthropology, sociology, literature and literary criticism, and much else.

So, when I came to create a women's studies course out of almost nothing in 1976, I used the knowledge I had gained as a women's movement activist. When I look over my old course outlines I am struck by how interdisciplinary they were, though I can detect a historian's distinctive interest in chronology and historical context for the discussion of ideas. One of the courses I created was called 'Changing concepts of woman's place in European thought'. This began with a discussion of Mary Wollstonecraft, and in particular her famous book $A$ Vindication of the Rights of Woman, first published in 1792, when English society was being shaken by the events of the French Revolution. It continued by looking at John Stuart Mill and Harriet Taylor, the suffrage movement, Friedrich Engels and Simone de Beauvoir. One of the essay questions I set my students was 'How relevant are Mary Wollstonecraft's arguments today?' and this gives a clue to the feminist interest in Wollstonecraft. We read her as being the first to insist on 
that fundamental proposition of 1970s feminism: that women's subordination was a social product and, as such, could be ended through social action. We saw her as - like us - interested in women's socialisation and education and as emphasising women's intellectual capacity and rights to freedom. We thought, rather condescendingly, that she did not follow her ideas through sufficiently, since she still thought women's primary responsibility was in the family, but she had made the breakthrough for others to build on.

When I left The Australian National University for the University of Technology, Sydney, in 1978, I continued to teach courses on women's history for several years, and Mary Wollstonecraft featured prominently in them. Gradually, however, my teaching changed to focus on other things, especially on histories of race relations and colonialism, and I rather forgot my knowledge of Wollstonecraft, Mill and the others. When I was invited in mid 2008 to contribute to the Key Thinkers lecture series, I thought of Mary Wollstonecraft, that key thinker for feminism that had so inspired me and my generation almost 40 years earlier. I wondered how she might look now, in the light of new questions and new intellectual frameworks for reading her.

In this rediscovery of Mary Wollstonecraft, I have found that interest in her has continued strongly since the 1970s, spread across a number of scholarly fields. These include political theory, philosophy, women's studies, literary studies and history. Reprising the 1970s feminist interest in interdisciplinary approaches to large questions, I want to use all of these to assist me in reading and rereading her work, especially her key text, A Vindication of the Rights of Woman.

First, however, some biography. For Mary Wollstonecraft, the tradition of reading her thought in relation to her life has been overwhelming, so much so that for many it is the life more than the thought that inspires. This is somewhat similar to much discussion of Simone de Beauvoir, whose life and especially her personal and sexual affairs have fascinated many readers at least as much as her ideas. ${ }^{1}$ For many feminists in the 1970 s and since, Wollstonecraft was not simply the person who said so early that women could have and be so much more than they currently were, but who in her own life demonstrated a free spirit, and an unconventionality, that most of us admire and aspire to. ${ }^{2}$ So, before getting into Wollstonecraft's ideas in any depth, I will, like most commentators and in the spirit of Hannah Arendt's approach in Men in Dark Times, in which she discusses thinkers in terms of biography, anecdote, vignette and social genealogy, start with her life. ${ }^{3}$

1 Curthoys, Ann 2002, 'Cultivating the arts of the female self: the micro politics of a re-fashioned feminism', in Jane Bennett and Michael J. Shapiro (eds), The Politics of Moralising, Routledge, New York.

2 As Cora Kaplan has noted, Wollstonecraft's 'life has been read much more closely than her writing' (Kaplan, Cora 2002, 'Mary Wollstonecraft's reception and legacies', in Claudia L. Johnson (ed.), The Cambridge Companion to Mary Wollstonecraft, Cambridge University Press, UK, p. 247). 


\section{Biography}

Although her many biographers have seen the life of Mary Wollstonecraft very differently - sometimes, for example, governed by ideas, other times by passion, sometimes as essentially secular and other times intensely religiouswe can draw from them the following sketch. Mary was born in London in 1759 into a middle-class family, but, with the family's fall in fortunes, she had of necessity when she reached adulthood to earn her own living. After working as a lady's companion, she became a teacher and governess for several years before becoming a full-time writer. Like many genteel women without sufficient financial support, Mary, with her two sisters and a close friend, Fanny Blood, set up a private school. The school was at Newington Green, close to a meeting house for Dissenters - part of an English radical tradition, who sought to rid religion of superstition. ${ }^{4}$ Her work as a teacher and her connections with the Dissenters both influenced her subsequent thinking and writing. When Fanny died several days after giving birth, and soon after the school failed, Mary spent a year in Ireland in 1786 as a governess. Here she began to write both fiction and non-fiction - her early published works including a conduct book called Thoughts on the Education of Daughters (1787) and a novel, Mary: A fiction (1788). At the age of twenty-eight, she abandoned teaching and moved to London, where she became a full-time professional writer. She wrote for the liberal publisher Joseph Johnson, translating texts from French and German and writing reviews for Johnson's journal, the Analytical Review. Through her writing, she mixed in radical circles, meeting people such as Thomas Paine, the English revolutionary pamphleteer, inventor and intellectual, who had participated in the American Revolution, and William Godwin, an English writer and radical philosopher. She now aspired, as she wrote to her sister in 1787, to be 'the first of a new genus': a self-supporting woman. ${ }^{5}$ She came to prominence in 1790 when she wrote a fiery response to Edmund Burke's essay on the French Revolution - her essay called A Vindication of the Rights of Men (1790), of which more later. It caused a stir at the time and was soon followed by $A$ Vindication of the Rights of Woman, completed early in 1792. While writing this work, she became passionately attached to the painter Henry Fuseli, but the friendship ended when Fuseli's wife angrily refused Wollstonecraft's suggestion she join the Fuseli household. While Mary had proposed a platonic living arrangement, she had also not hidden her strong feelings for Henry. ${ }^{6}$

4 Todd, Janet 2000, Mary Wollstonecraft: A revolutionary life, Columbia University Press, New York, pp. $57-9$.

5 Sunstein, Emily W. 1975, A Different Face: The life of Mary Wollstonecraft, Harper and Row, New York, p. 152.

6 Todd, Mary Wollstonecraft, p. 198. 
Soon after, Wollstonecraft travelled to France and wrote about what was happening to the French Revolution, which she and her friends had so admired in its early stages. She wrote a history of this period called An Historical and Moral View of the French Revolution, which was published at the end of 1794. In France, she met an American, Gilbert Imlay, who had fought in the American War of Independence and was now in Paris for business reasons, and the friendship became a sexual affair. When France declared war on Britain in 1793, British citizens in France were in danger and, as a protective measure (at this point the United States and France were allies), Wollstonecraft took on the identity of Mrs Imlay, though she and Gilbert Imlay were not married. In May 1794, she gave birth to their daughter, Fanny Imlay. Soon after, Imlay left for London; when Mary also returned to London, in April the next year, and learned of the extent of his withdrawal from her and his infidelity, she attempted suicide. Only two weeks later, she travelled to Sweden with her baby and a maid to undertake some business dealings for Imlay, perhaps in the hope that they would be reunited. Her travels lasted from June to September and took her also to Norway and Denmark. Her letters to Imlay written during her travels were published as Letters Written During a Short Residence in Sweden, Norway, and Denmark in 1796. Part travelogue and part personal reflections, this book became her most popular during her lifetime. With its dramatic descriptions of landscape, events and people in a time of revolutionary turmoil, its popularity has endured and it is still in print today. ${ }^{7}$

On her return to England, Wollstonecraft rejoined London literary life and this time she and William Godwin became lovers. Godwin had read and admired her Letters Written During a Short Residence in Sweden, Norway, and Denmark and later famously wrote that ' $[\mathrm{i}] \mathrm{f}$ ever there was a book calculated to make a man in love with its author, this appears to me to be the book' ${ }^{8}$ When Wollstonecraft became pregnant, the couple married in March 1797, but, somewhat disastrously for Mary's social respectability, the marriage revealed she had never been married to Imlay. Mary and William lived in two adjoining houses in order to retain their independence, so their marriage was hardly conventional. Tragically, Mary died in childbirth in August 1797, at the age of thirty-seven. An unfinished novel, Maria, or the Wrongs of Woman, was published the next year, as was the first biography of her life, Godwin's frank and controversial Memoirs of the Author of A Vindication of the Rights of Woman. ${ }^{9}$

\footnotetext{
7 Wollstonecraft, Mary 2009 [1796], Letters Written in Sweden, Norway, and Denmark, Edited and with an introduction and notes by Tone Brekke and Jon Mee, Oxford World's Classics, Oxford University Press, UK. 8 Godwin, William 1798, Memoirs of the Author of A Vindication of the Rights of Woman, J. Johnson, London, available in full text on Google Books, viewed 20 July 2010, <http://books.google.com.au/books?id $=7$ msEAAAAYAAJ\&printsec $=$ frontcover $\& \mathrm{dq}=$ Memoirs + of + the + Author + of + A + Vindication + of + the + Righ ts + of + Woman \&cd $=1 \# \mathrm{v}=$ onepage $\& \mathrm{q} \& \mathrm{f}=$ false $>, \mathrm{p} .133$.

9 Biographies of Mary Wollstonecraft include - in addition to Todd, Mary Wollstonecraft, cited above: Gordon, Lyndall 2005, Vindication: A life of Mary Wollstonecraft, Virago, London; and Tomalin, Claire 1992
} 


\section{A Vindication of the Rights of Men (1790)}

In a polemical age, Wollstonecraft's writing was as passionate and transgressive as her life. Before looking in detail at her most famous work, I want to discuss for a moment its immediate predecessor, A Vindication of the Rights of Men. This was written in response to Edmund Burke's famous Reflections on the French Revolution, itself a response to an address supporting the French Revolution by a member of Wollstonecraft's circle, Richard Price. Burke was a curious figure, having supported the American Revolution and spoken out fiercely against British imperial practices in India and Ireland. ${ }^{10}$ Now he spoke clearly as a conservative, preferring continuity, tradition and hierarchy to revolutionary talk of the rights of man and the overthrow of one political regime by another. There were many responses to Burke's Reflections - the most famous being Tom Paine's Rights of Man - but in fact Wollstonecraft's Vindication of the Rights of Men was the first to appear. In its day it had a considerable impact, making Wollstonecraft instantly a well-known writer and commentator. ${ }^{11}$

Wollstonecraft's own approach to Burke is in part biographical, presenting him as a once admirable man, now grown old (he was sixty-one) and too ready to rationalise the interests of the rich and powerful. Where Burke urges respect for existing institutions and traditions, Wollstonecraft urges radical change. She draws some of her ideas from those of the Scottish Enlightenment - in particular, those thinkers who suggested a history of human improvement, as societies progressed through four stages, from savagery to pastoralism to agriculture to commerce and industry. ${ }^{12}$ Societies in the most advanced stage should not, she thinks, base their arrangements on institutions developed in an earlier stage. So, for example, to Burke's appeal to the English Constitution, Wollstonecraft replies that 'the constitution, if such an heterogeneous mass deserve that name, was settled in the dark days of ignorance, when the minds of men were shackled by the grossest prejudices and most immoral superstition' ${ }^{13}$

Wollstonecraft is scathing about Burke's defence of the rights of property. 'To this selfish principle [security of property],' she writes 'every nobler one is sacrificed. ${ }^{14}$ Furthermore, 'it is only the property of the rich that is secure; the man who lives by the sweat of his brow has no asylum from oppression... when

[1974], The Life and Death of Mary Wollstonecraft, Penguin, Harmondsworth, UK; Johnson, The Cambridge Companion to Mary Wollstonecraft, also has considerable biographical information.

10 For a detailed discussion of Burke's views on India and Ireland, see: Pitts, Jennifer 2005, A Turn to Empire: The rise of imperial liberalism in Britain and France, Princeton University Press, NJ, ch. 3.

11 Wollstonecraft, Mary 1790, A Vindication of the Rights of Men, The Online Library of Liberty, viewed 30 March 2010, <http://files.libertyfund.org/files/991/Wollstonecraft_0532_EBk_v5.pdf>

12 See Jane Rendall's excellent discussion in " The grand causes which combine to carry mankind forward": Wollstonecraft, history and revolution', Women's Writing, vol. 4 no. 2 (1997), pp. 155-72.

13 Wollstonecraft, A Vindication of the Rights of Men, p. 10.

14 Ibid., p.12. 
was the castle of the poor sacred $?^{\prime 15}$ She sees Burke as having contempt for the poor, when he says 'the people, without being servile, must be tractable and obedient', and also when he says that if some people find they have less than others, 'they must be taught their consolation in the final proportions of eternal justice'. Wollstonecraft replies that it is possible to make the poor happier in this world, as well as the next. 'They have a right to more comfort than they at present enjoy' and this will be achieved not through charity but through finding them work 'calculated to give them habits of virtue'. ${ }^{16}$ She wants more economic justice, asking that large estates be divided into small farms and that the peasants have rights to what was common land. ${ }^{17}$ The world she sees as often a place of misery: 'hell stalks abroad; - the lash resounds on the slave's naked sides; and the sick wretch, who can no longer earn the sour bread of unremitting labour, steals to a ditch to bid the world a long good night... Such misery demands more than tears. ${ }^{18}$ Her vision of slave and feudal society reminds us, perhaps, of Dante's phantasmagorical vision of the Inferno.

Invoking the principles of natural law, Wollstonecraft argues for the 'rights which men inherit at their birth, as rational creatures, who were raised above the brute creation by their improvable faculties' ${ }^{19}$ She is also scornful of the idea that one must submit to existing authority. Burke, she thinks, seems to defend slavery, and she responds that if we are to revere antiquity and self-interest as much as Burke does, it would follow that 'the slave trade ought never to be abolished' - the actions of our ignorant forefathers would have, in Burke's train of reasoning, to be supported and maintained. ${ }^{20}$ She returns to the question of slavery later: 'is it not consonant with justice, with the common principles of humanity, not to mention Christianity, to abolish this abominable mischief?'21

Wollstonecraft is scornful of English social life, in which, largely as a result of the system whereby land and property are inherited, marriage is so often delayed. This means, she says, 'our young men become selfish coxcombs' and women 'flatter the spring of life away, without laying up any store for the winter of age, or being of any use to society' ${ }^{22}$ Her target is the aristocracy and even more those of the middle class who ape aristocratic manners. She scorns the 'luxury

\footnotetext{
Ibid., p. 12.

Ibid., pp. 41, 42.

Ibid., p. 42.

Ibid., p. 43.

Ibid., p. 11.

20 Ibid., p. 12.

Ibid., p. 38.

2 Ibid., pp. 17, 18.
} 
and effeminacy' that 'introduce so much idiotism into the noble families' ${ }^{23}$ Such men can hardly be educated in the arts of life when all their wants are so instantly supplied and 'invention is never sharpened by necessity'. ${ }^{24}$

Wollstonecraft was a devout dissenting Christian who we can place in a long Enlightenment tradition of Christian humanism that was critical of institutional Christianity. As Barbara Taylor suggests, the 'centrality of religion to Wollstonecraft's worldview is evident in virtually every aspect of her thought, from her uncompromising egalitarianism to her hostility toward British commercialism...to her ardent faith in an imminent age of universal freedom and happiness' ${ }^{25}$ Here, in A Vindication of the Rights of Men, Wollstonecraft argues that 'to act according to the dictates of reason is to conform to the law of God'.$^{26}$ She is, however, quite scathing about God's representatives on Earththe British clergy - who are dependent on the aristocracy for their income and who practise their profession for money rather than conviction. ${ }^{27}$ She is equally scornful of the British Parliament, in which most MPs have gained their seats through their fortune and hereditary rank. ${ }^{28}$

A Vindication of the Rights of Men also ponders a classic Enlightenment concern with the relationship between reason and the passions. Though often interpreted as positing a dualism between the two, Wollstonecraft in this text is arguing in the tradition of Spinoza that they are entwined. ${ }^{29}$ Both reason and passion are necessary. Passions, she writes, 'are neither good nor evil dispositions, till they receive a direction'. The direction they need comes from reason and if reason directs passion, virtue is the result. ${ }^{30}$ For virtue to become the aim of all, society will need to change and there will need to be less respect for rank. 'Such a glorious change,' she writes, 'can only be produced by liberty. Inequality of rank must ever impede the growth of virtue, by vitiating the mind that submits or domineers. ${ }^{31}$ 


\section{A Vindication of the Rights of Woman (1792)}

With the success of her pamphlet, Wollstonecraft immediately sat down and wrote another. It took her six weeks and this was the famous $A$ Vindication of the Rights of Woman, which first appeared in $1792 .{ }^{32}$ It is in part a much more orderly and well-argued restatement of the themes of the first Vindication, but it also offers something entirely new in its focus on society's false dichotomy between the sexes. Addressing the French revolutionaries in particular, Wollstonecraft writes: 'If the abstract rights of man will bear discussion and explanation, those of woman, by a parity of reasoning, will not shrink from the same test. ${ }^{33}$ It was inconsistent for men seeking their own freedom, as the French revolutionaries claimed to be, to 'subjugate women'.$^{34}$ Indeed, to deny women their freedom, to refuse to acknowledge their capacity for reason and virtue, was to act like a tyrant. 'Do you not act a similar part,' she asked Talleyrand in the introduction, 'when you FORCE all women, by denying them civil and political rights, to remain immured in their families groping in the dark?' If women are granted their rights, 'the sexes will fall into their proper places'. ${ }^{35}$

She then turns to one of her main themes: that women, through lack of respect for their powers of reason, are rendered 'weak and wretched...The conduct and manners of women, in fact, evidently prove, that their minds are not in a healthy state'.$^{36}$ She is indeed very harsh on women. Men complain, she writes, 'and with reason, of the follies and caprices of our sex...our headstrong passions and groveling vices'. Her explanation, however, is that women are socialised to seek male protection rather than support themselves. 'Women are told from their infancy, and taught by the example of their mothers,' she rails,

that a little knowledge of human weakness, justly termed cunning, softness of temper, OUTWARD obedience, and a scrupulous attention to a puerile kind of propriety, will obtain for them the protection of man; and should they be beautiful, every thing else is needless, for at least twenty years of their lives. ${ }^{37}$

It is not only this debilitating and degrading socialisation of women that is at fault, it is also their subjection to 'a false system of education, gathered from the books written on this subject by men, who, considering females rather as women than human creatures, have been more anxious to make them alluring

32 Wollstonecraft, Mary 1792, A Vindication of the Rights of Woman, viewed 30 March 2010, <http://www. gutenberg.org/dirs/etext02/vorow10.txt>

33 Wollstonecraft, A Vindication of the Rights of Woman, p. 7.

34 Ibid., p. 8.

35 Ibid., p. 8

36 Ibid., p. 9.

37 Ibid., p. 20 
mistresses than rational wives'.$^{38}$ In her emphasis on education, Wollstonecraft was influenced by a long Enlightenment tradition-evident in the work of Lady Mary Wortley Montagu, Mary Astell and most importantly in Catherine Macaulay's Letters on Education, published only two years before-which argued against the system of trivial female upbringing and urged that girls be given a sound and serious education.

Wollstonecraft comes back to the point of women's socialisation and education throughout the Vindication. Again and again, she opposes the arguments of those who deduce from men's greater physical strength the necessity for women's inferior social position. 'In the government of the physical world,' she says, 'it is observable that the female, in general, is inferior to the male...But not content with this natural pre-eminence, men endeavour to sink us still lower, merely to render us alluring objects for a moment.' ${ }^{39}$ She acknowledges that women's 'apparent inferiority with respect to bodily strength, must render them, in some degree, dependent on men in the various relations of life' but then goes on to question why this dependence should be increased by the unfounded prejudice that only men can attain virtue. ${ }^{40}$

Much of Wollstonecraft's text is taken up with exploring the details of what is wrong in the current social expectations of both men and women. She attacks the aristocratic lifestyle as much as the degradation of women, urging that middle-class women - growing in number and influence - refrain from imitating their aristocratic counterparts. She despises the rich and inveighs against them repeatedly: 'the education of the rich tends to render them vain and helpless, and the unfolding mind is not strengthened by the practice of those duties which dignify the human character. They only live to amuse themselves.' ${ }^{41}$

Men, says Wollstonecraft, address women 'as if they were in a state of perpetual childhood'. She wants women to be, and to be seen to be, humans with reasoning capacities the equal of men's. 'I wish to persuade women to endeavour to acquire strength, both of mind and body, and to convince them, that the soft phrases, susceptibility of heart, delicacy of sentiment, and refinement of taste, are almost synonymous with epithets of weakness.' As objects of pity, they are in danger of becoming objects of contempt. ${ }^{42}$

What women should be seeking, she suggests, is not elegance and beauty and male admiration, but virtue and strong character. ${ }^{43}$ For Wollstonecraft, reason and virtue are what distinguish humans - men and women-from the brutes,

38 Ibid., p. 10.

39 Ibid., p. 10.

40 Ibid., p. 13.

41 Ibid., p. 11.

42 Ibid., p. 11.

43 Ibid., p. 12. 
from the animal world. The passions are implanted in humans so that man 'by struggling with them might attain a degree of knowledge denied to the brutes' ${ }^{44}$ Again reminding us of Spinoza, she writes that humans are God's creation: 'When that wise Being, who created us and placed us here, saw the fair idea, he willed, by allowing it to be so, that the passions should unfold our reason.' ${ }^{45}$

Wollstonecraft could be alternately cautious and bold. Disappointingly for twentieth-century feminists, she says little about women's political rights, apart from noting cryptically: 'I may excite laughter, by dropping a hint, which I mean to pursue, some future time, for I really think that women ought to have representatives, instead of being arbitrarily governed without having any direct share allowed them in the deliberations of government. ${ }^{\prime 46}$

If later feminists were, however, to find Wollstonecraft wanting on the issue of formal citizenship, they could hardly fault her as a critic of what they came to call 'sex roles'. This time the laughter she feared her ideas would excite was loud indeed:

A wild wish has just flown from my heart to my head, I will not stifle it though it may excite a horse-laugh.-I do earnestly wish to see the distinction of sex confounded in society, unless where love animates the behaviour. For this distinction is, I am firmly persuaded, the foundation of the weakness of character ascribed to woman. ${ }^{47}$

In this second Vindication, Wollstonecraft again reprises Scottish Enlightenment stadial theory. She sees history as a story of progress from one stage to the next, starting with barbarism and continuing with the development of an aristocracy and monarchy. The transition towards more rational and democratic forms, however, is by no means simple. On the one hand, the people over time demand more power and their minds are expanded through 'wars, agriculture, commerce, and literature... Men of abilities scatter seeds that grow up, and have a great influence on the forming opinion; and when once the public opinion preponderates, through the exertion of reason, the overthrow of arbitrary power is not very distant'. On the other, she is intensely aware of the forces of reaction and the ability of despots to hold onto their power. The progress of reason is no simple matter. One problem is the continuing power of professions such as the military, the navy and the clergy ('the pestiferous purple') in which there is

\footnotetext{
44 Ibid., p. 14.

45 Ibid., p. 16.

46 Ibid., p. 137.

47 Ibid., p. 54.
} 
'great subordination of rank'. As society becomes more enlightened, it should, she warns, be careful 'not to establish bodies of men who must necessarily be made foolish or vicious by the very constitution of their profession' ${ }^{48}$

A Vindication sometimes seeks to strengthen its argument against despotismand for the importance of reason - through a contrast of Europe and the West. When it criticises the ways women are treated in Europe, it likens such treatment to practices in the East: 'To preserve personal beauty...the limbs and faculties are cramped with worse than Chinese bands. ${ }^{49}$ Uneducated women are 'weak beings only fit for the seraglio'.$^{50}$ It scorns the English 'husband who lords it in his little harem' and who 'thinks only of his pleasure or his convenience' ${ }^{51}$ Sometimes there are specific references to 'Mahometanism', or Islam. It says of women generally at one point, for example: 'in the true style of Mahometanism, they are only considered as females, and not as a part of the human species. ${ }^{.52}$ A few pages later, Wollstonecraft remarks that she does not understand what the poet Milton meant when he 'tells us that women are formed for softness and sweet attractive grace', unless, she says, 'in the true Mahometan strain, he meant to deprive us of souls'. ${ }^{33}$ Though Mary Wortley Montagu had already disputed the idea that Islam accorded souls only to men, it had by this time become an Orientalist commonplace. ${ }^{54}$ As Joyce Zonana suggests, Wollstonecraft is asking England to rid itself of Oriental ways and to become more rational, enlightened and reasonable. ${ }^{55}$

In this Vindication, Wollstonecraft also makes many references to slavery-more than 80, according to Moira Ferguson. ${ }^{56}$ Some of these are direct references to the African slave trade and the movement for its abolition then under way, while others are metaphorical references comparing women's subjected state with a state of slavery. The analogy becomes very clear when Wollstonecraft asks: 'Is one half of the human species, like the poor African slaves, to be subject to prejudices that brutalize them' ${ }^{57}$ These references echo the views of the antislavery movement of the period, especially the idea that slavery degrades both

\footnotetext{
48 Ibid., pp. 18-19.

49 Ibid., p. 40.

50 Ibid., p. 12.

51 Ibid., p. 68.

52 Ibid., p. 10.

53 Ibid., p. 20.

54 See Andrea, Bernadette 2009, 'Islam, women, and Western responses: the contemporary relevance of early modern investigations', Women's Studies, vol. 38, no. 3, p. 284. Andrea quotes Montagu as saying 'our vulgar notion that they [Muslims] do not own women to have any souls is a mistake', quoting from Wortley Montagu, Mary 1993, Turkish Embassy Letters, Edited by Malcolm Jack, University of Georgia Press, Athens, p. 100.

55 Zonana, Joyce 1993, 'The sultan and the slave: feminist Orientalism and the structure of Jane Eyre', Signs, vol. 188, no. 3 (Spring), pp. 592-617, esp. p. 602.

56 Ferguson, Moira 1993, Colonialism and Gender Relations from Mary Wollstonecraft to Jamaica Kincaid, Columbia University Press, New York, p. 9

57 Wollstonecraft, A Vindication of the Rights of Woman, p. 135.
} 
master and slave. Women, Wollstonecraft writes, 'may be convenient slaves, but slavery will have its constant effect, degrading the master and the abject dependent'. ${ }^{58}$

And so I could go on. Despite being somewhat repetitive, this is a lively text. It is so strong in its denunciation of both despotism and weakness and so intense in its moral seriousness that it carries the reader along. When I came back to this text after many years, I was captivated all over again by its passionate defence of reason and its reasoned discussion of passion. It is not, however, a simple or even an entirely consistent text and many different readings and responses are possible. It is not surprising that it has been interpreted and understood in very different ways in the two centuries since its first appearance. It is to these divergent readings that I now turn.

\section{How Wollstonecraft has been read and remembered}

Several months after Wollstonecraft's death, as indicated earlier, William Godwin published Memoirs of the Author of A Vindication of the Rights of Woman. Though written affectionately, these memoirs, revealing to all the world as they did Wollstonecraft's turbulent love affairs, the fact that Fanny Imlay was illegitimate and her two suicide attempts in 1795, had an extremely damaging effect on her reputation. Her sexual life was seen as shocking at the time and this perception negatively affected the reception of her work. Few nineteenthcentury English feminists read her, so unrespectable had she become. Barbara Caine tells us that 'Wollstonecraft was not so much unknown to mid-Victorian feminists... as carefully and consciously avoided, especially in their published and public work' ${ }^{59}$ For many decades, Wollstonecraft's work was also seen as poorly argued, as itself emotional and governed by passion rather than reason. Courageously, George Eliot in an essay in 1855 disagreed, seeing A Vindication of the Rights of Woman as 'eminently serious, severely moral, and withal rather heavy', suggesting that Wollstonecraft's scandalous private life should be seen as an entirely separate matter. ${ }^{60}$

It was not really until the 1880s that Wollstonecraft's reputation as a thinker began to revive, and new editions of the Vindication were published in the 1890s. Yet the 1890s women's movement had serious disagreements with Wollstonecraft. In particular, in contrast with her railing at the moral inferiority of women

58 Ibid., p. 8

59 Caine, Barbara 1997, 'Victorian feminism and the ghost of Mary Wollstonecraft', Women's Writing, vol.

4, no. 2, pp. 261-75, quote on p. 262.

60 Ibid., p. 267. 
arising from their lack of education, Victorian feminists thought women more moral than men and argued for the greater influence of this morality in society. Furthermore, their focus was by this time on suffrage, and here Wollstonecraft was of little use, having made only fleeting references to the idea of women's political representation. It was only after the gaining of the vote that feminists began to read Wollstonecraft in more positive terms.

As Eileen Botting and Christine Carey indicate, Wollstonecraft's reputation fared somewhat better in America, though there too she was regarded as scandalous and was not widely read or discussed. ${ }^{61}$ Some leading feminist figures in the United States, however, did read and learn from her. Hannah Mather Crocker wrote a treatise on women's rights in 1818 that refers to Wollstonecraft and which develops rather similar arguments - such as noting the theological basis for the idea of the equal intellectual capacities of the sexes, the belief in friendship as a foundation for marriage and a critique of women's superficial education. Margaret Fuller discussed Wollstonecraft in her landmark work on sex equality, Woman in the Nineteenth Century, published in $1843 .{ }^{62}$ Lucretia Mott, an American Quaker minister, social reformer, advocate of the abolition of slavery and proponent of women's rights, was an admirer of Wollstonecraft's ideas. When she met Elizabeth Cady Stanton, another leading American feminist, in London at the World's Anti-Slavery Convention in 1840, she expressed her enthusiasm for Wollstonecraft, which Stanton soon came to share. Stanton's close friend Susan B. Anthony, another leading American feminist, also saw Wollstonecraft as an early proponent of the idea that men and women should share equal rights and an equal education and that women would be ennobled by economic independence. Mott gave many speeches encouraging women to study Mary Wollstonecraft, such as one at the National Woman's Rights Convention in 1866, and in the late 1860s Stanton and Anthony's women's rights newspaper, The Revolution, devoted many essays and letters to the analysis and interpretation of $A$ Vindication of the Rights of Woman. Both Stanton and Anthony later wrote works drawing attention to Wollstonecraft's importance. ${ }^{63}$

The attachment of feminists to Wollstonecraft grew in the twentieth century. In 1911, leading anarchist Emma Goldman delivered a lecture in New York entitled 'Mary Wollstonecraft, the pioneer of modern womanhood', in which she expressed enormous admiration for and identification with her subject. ${ }^{64}$ Possibly inspired by a new biography by G. R. Stirling Taylor, which had just

61 Hunt Botting, Eileen and Carey, Christine 2004, 'Wollstonecraft's philosophical impact on nineteenthcentury American women's rights' advocates', American Journal of Political Science, vol. 48, no. 4 (October), pp. 707-22.

62 Ibid., pp. 715-16.

63 Ibid., p. 718.

64 The lecture is reprinted in Wexler, Alice and Goldman, Emma 1981, ‘Emma Goldman on Mary Wollstonecraft', Feminist Studies, no. 1 (Spring), pp. 113-21. 
appeared, she saw Wollstonecraft as a person ahead of her time, a pioneer and a pathfinder whose life could be an inspiration to modern women. Wollstonecraft's tragic life, Goldman said, 'proves that economic and social rights for women alone are not enough to fill her life, nor yet enough to fill any deep life, man or woman'. ${ }^{65}$ Goldman's fascination was with the life at least as much as the text and the lecture concluded: 'had Mary Wollstonecraft not written a line, her life would have furnished food for thought. But she has given both, she therefore stands among the world's greatest, a life so deep, so rich, so exquisitely beautiful in her complete humanity. ${ }^{\prime 66}$

After the vote for women was won in the United States (in 1920) and the United Kingdom (in 1918 for women over thirty, and in 1928 for women over twenty-one), feminism's focus shifted to include a range of economic, social and sexual issues. In this new situation, Wollstonecraft's lack of interest in political representation mattered less and her emphasis on issues such as reason and passion, education, marriage and independence counted more. ${ }^{67}$ Virginia Woolf, for example, published an essay in 1932 that recounted Wollstonecraft's tragically short life and emphasised her interest in the French Revolution. ${ }^{68}$ She wrote feelingly of Wollstonecraft's reaction when she learned, after her return to London in 1795, that her lover, Imlay, had been unfaithful to her: 'Mary at once soaked her skirts so that she might sink unfailingly, and threw herself from Putney Bridge. But she was rescued; after unspeakable agony she recovered.' ${ }^{69}$ One cannot help wondering about Woolf's own suicide by drowning, in which she filled her pockets with stones to ensure that her body sank. At the end of the essay, Woolf suggests that Wollstonecraft

has her revenge...as we read her letters and listen to her arguments and consider her experiments... and realise the high-handed and hotblooded manner in which she cut her way to the quick of life, one form of immortality is hers undoubtedly: she is alive and active, she argues and experiments, we hear her voice and trace her influence even now among the living. ${ }^{70}$

Serious scholarly interest in Wollstonecraft, though, really had to wait until the 1970s, as feminism began its impact on the academy, and this was just the time when she and I, as it were, first became acquainted. As Cora Kaplan has said, 'Wollstonecraft as an historical icon had become deeply - too deeply perhaps-

\footnotetext{
65 Ibid., p. 116.

66 Ibid., p. 121. For discussion of the influence of the Stirling Taylor biography, see Wexler, Alice 1981, 'Afterword', Feminist Studies, no. 1 (Spring), p. 123.

67 Caine, 'Victorian feminism and the ghost of Mary Wollstonecraft', p. 271-2.

68 Woolf, Virginia 1935, 'The four figures', The Common Reader, Second series, viewed 30 March 2010, $<$ http://ebooks.adelaide.edu.au/w/woolf/virginia/w9lc2/chapter13.html>

69 Ibid., p. 5.

70 Ibid., p. 7.
} 
articulated with the hopes and fears of the second wave of the women's movement'. She was, to quote Kaplan again, 'simultaneously reinvented as the foremother of a radical brand of liberalism, a precursor of utopian socialism, a bold fore-runner of the sexual revolution and a more bounded and conservative proponent of bourgeois femininity' ${ }^{71}$ She was often chastised, in a very ahistorical way, for accepting women's role in the family, for her emphasis on women's shortcomings or for having no political program for change. Sheila Rowbotham is quite typical of second-wave feminism's view in her own groundbreaking book, Women, Resistance and Revolution (1972), when she says:

[W]hile Mary Wollstonecraft could observe so acutely the distress of bourgeois women...she falters when she tries to find the means of effecting the social change her analysis demands...she cannot conceive of women becoming the agents of their own liberation. She can only hope to convince reasonable men to assist in the emancipation of their companions. ${ }^{72}$

\section{Recent readings}

Mary Wollstonecraft continues to be read today, but more by specialised scholars, in fields such as political theory, literary criticism, history and postcolonial theory, than by that broader feminist reading public that so warmed to her in the 1970 s. ${ }^{73}$ Her lesser-known works, in particular, are receiving increased attention.

Political theorists have sought to understand her not only as a feminist but also as an Enlightenment thinker. Virginia Sapiro emphasises the fact that she was part of a London-based community of intellectuals who were religious Dissenters and who thus personally understood the denial of civil and political rights, and who were furthermore avid supporters of the early stages of the French Revolution. ${ }^{74}$ This circle, however, was not feminist, and Sapiro suggests that we might see Wollstonecraft not as one of the first feminist philosophers but rather as a pre-feminist struggling towards a feminist vocabulary. Her key terms were reason, independence, virtue, progress, education and enlightenment, and Sapiro reminds us that these terms had different meanings then from now. Reason, for example, was not some cold mathematical abstraction but a matter of the 'association of ideas' - the active process of reaching understanding from

\footnotetext{
71 Kaplan, 'Mary Wollstonecraft's reception and legacies', p. 2.

72 Rowbotham, Sheila 1974 [1972], Women, Resistance and Revolution, Penguin, Harmondsworth, UK, p. 44.

73 See Johnson, The Cambridge Companion to Mary Wollstonecraft, p. 5.

74 Sapiro, Virginia 1998, 'A woman's struggle for a language of enlightenment and virtue: Mary Wollstonecraft and Enlightenment "feminism"', in Tjitske Akkerman and Siep Stuurman (eds), Perspectives of Feminist Political Thought in European History, Routledge, London, pp. 122-35, quote on p. 125.
} 
experience. Education did not refer only to formal training received in schools but to something more like what 'socialisation' means today. Sapiro draws attention to Wollstonecraft's repeated emphasis on the wrongs of hierarchy and subordination, damaging the minds and character of both the dominant and subordinate partners. ${ }^{75}$

Wollstonecraft has been of great interest for literary critics focused on the 1790s and Romanticism. As the critic Simon Swift points out, recent British studies of the intellectual culture of this period 'abound with attempts to rediscover a lost relation between affect and reason', especially in literary forms that enable the rational self to be transported with enthusiasm without losing its sense of itself. These studies look at 'specific and significant moments of transaction between sensation and thought'. In this school of thought, Mary Wollstonecraft becomes significant for her discussion of the relationship between reason and emotion, or passion. Far from being trapped in a dualism of reason versus emotion, as many have assumed, Wollstonecraft in this view becomes part of the emergence of a liberated romantic enthusiasm that continues to negotiate with Enlightenment notions of reason. ${ }^{76}$

Especially important has been the intervention from post-colonial theorists. Drawing on Edward Said's notions of Orientalism, Joyce Zonana wrote a stunning and influential essay in 1993, drawing attention to the phenomenon of feminist Orientalism, in which Wollstonecraft can be recognised as a leading figure. ${ }^{77}$ Zonana's reading has certainly influenced my own. Throughout the eighteenth century, Zonana says, images of despotic Eastern sultans and desperate slave girls became part of liberal discourse and, as feminism emerged, of liberal feminist discourse. Liberals and feminists consistently used the Orient as a vehicle to criticise the West, likening to the Orient those aspects of Western society they opposed. Their interest in the Orient was directed not towards understanding the East itself but towards transforming Western society. Zonana traces the Western use of the harem as a metaphor for Eastern life to Montesquieu's Persian Letters, published in 1721. This novel, structured through letters written by two Persian men travelling in Europe, constantly compares the domestic and political relations of East with West. It is especially concerned with the hareman image of the domestic enslavement of women that functions as a metaphor for the political enslavement of men. ${ }^{78}$ In both France and England thereafter, the harem came to function as a metaphor for the Western oppression of women-

\footnotetext{
75 Ibid., p. 130.

76 Swift, Simon 2006, 'Mary Wollstonecraft and the "reserve of reason"', Studies in Romanticism, vol. 45, no. 1 (Spring), pp. 3-24, 153. See also Taylor, Barbara 2002, Mary Wollstonecraft and the Radical Imagination, Cambridge University Press, UK.

77 Zonana, 'The sultan and the slave', pp. 592-617.

78 Ibid., p. 598.
} 
for example, in Samuel Johnson's Rasselas in 1759. It is, Zonana contends, in Wollstonecraft's A Vindication of the Rights of Woman that feminist Orientalism really emerges.

Since Zonana's article appeared, a number of scholars have further explored the history of feminist Orientalism and Wollstonecraft's place in it. In a 2009 article, Bernadette Andrea traces the genealogy of the Western trope that Muslim women were especially oppressed as far back as the early seventeenth century. She considers male travel writers such as William Biddulph, who in The Travels of Certaine Englishmen into Africa, Asia, Troy... and to sundry other places (1609) introduced the idea that Muslim women were virtually slaves and that English women should feel grateful for their own much better situation. ${ }^{79}$ William Lithgow wrote about his travels to 'the most famous Kingdomes in Europe, Asia and Affricke' in 1614, in which he deemed Turkish wives as like slaves, since the Qur'an permits men to marry as many women as they wish. ${ }^{80}$ At some time during the seventeenth century, the idea of Eastern women's subjection entered the slowly emerging feminist discourse. At the end of the century, the anonymous writer of An Essay in Defence of the Female Sex... Written by a Lady (1696) wrote of 'the Eastern parts of the World, where the Women, like our Negroes, in our Western Plantations, are born slaves, and live Prisoners all their Lives'. ${ }^{81}$ The idea took further hold during the eighteenth century, though it was also contested-notably by Mary Wortley Montagu. ${ }^{82}$ In her Turkish Embassy Letters, Montagu writes that she had learned on her travels (in 171618) that Turkish women had property rights denied to Englishwomen, even aristocratic ones such as herself. ${ }^{83}$ She is also impressed by women's right to privacy. When Mary Astell, a feminist writer of the late seventeenth and early eighteenth centuries, was asked in 1724 to write a preface to the Letters, she condemned the male travel writers responsible for the idea of Muslim women's virtual slavery. ${ }^{84}$

The idea of Muslim women's subjection, however, took hold. Bernadette Andrea directs our attention to The Hardships of the English Laws in Relation to Wives, written by an anonymous female author and published in 1735, which emphasises and critiques the power of men over their wives in England by comparing it with the despotic power of 'the Grand Seignior in his Seraglio'; they differ only in that while the Englishman has one vassal, the grand seignior has many. ${ }^{85}$ Eighteenth-century women writers such as Penelope Aubin and

79 Andrea, 'Islam, women, and Western responses', p. 277.

80 Ibid., p. 278.

81 Ibid., p. 281.

82 Ibid., p. 274.

83 Ibid., p. 278.

84 Ibid., pp. 280-1.

85 Ibid., p. 285. See also Anonymous 1990, 'The hardships of the English laws in relation to wives', reprinted in Vivien Jones (ed.), Women in the Eighteenth Century: Constructions of femininity, Routledge, London, p. 218. 
Eliza Haywood wrote popular narratives about 'white women living as captives in Islamic harems', while the plays of successful dramatist Susanna Centlivre also deployed the notion of the oppression of women in the East. ${ }^{86}$ By the end of the century, when Mary Wollstonecraft was writing, the idea of Eastern, including Muslim, women's subjection was well known.

Post-colonial criticism also directs our attention to Wollstonecraft's use of antislavery discourse to strengthen her argument for the rights of women. Literary critic Deirdre Coleman points out that the existence of slavery in the British West Indies led feminist writers to expand their slavery analogies from the seraglios of the East to the sugar plantations of the West. ${ }^{87}$ This is especially clear in An Essay in Defence of the Female Sex... Written by a Lady (1696), quoted above, which likens the slavery of women in the East to that of 'our Negroes, in our Western Plantations' ${ }^{88}$ As Andrea points out, this text supports Englishwomen's claims for individual liberty by contrasting them with both 'the imagined slavery of Muslim wives and the actual slavery of Africans in the "New World"". ${ }^{89}$ This discursive strategy, which lasted well into the nineteenth century in the context of US debates over slavery, has been criticised by recent scholars. Coleman, for example, criticises 'the emotive but clichéd analogy between their [white feminists'] own disenfranchised lot and the plight of enslaved Africans'.$^{90}$ She reminds us that bell hooks argued tellingly in 1981 that the analogy between the situation of white women and black people is a deeply conservative one aimed at upholding the racial hierarchy that places white people above black. It gains its charge from the idea that white women have been allowed to sink to the status of black people and must be rescued. I have argued previously that something similar occurs when modern feminists seek to adopt the metaphor of 'colonisation' to describe women's subjection; the notion of white women's 'colonisation' displaces, and makes it harder to understand, the drastic consequences of colonisation by European empires for indigenous peoples. ${ }^{91}$

\footnotetext{
86 Andrea, 'Islam, women, and Western responses', p. 286. See also Long Hoeveler, Diane 2006, 'The female captivity narrative: blood, water, and Orientalism', in Diane Long Hoeveler and Jeffrey Cass (eds), Interrogating Orientalism: Contextual approaches and pedagogical practices, Ohio State University Press, Columbus, p. 52.

87 Coleman, Deirdre 1994, 'Conspicuous consumption: white abolitionism and English women's protest writing in the 1790s', ELH, vol. 61, no. 2, pp. 341-62, see esp. p. 351.

88 As quoted in Andrea, 'Islam, women, and Western responses', p. 281.

89 Ibid., p. 283.

90 Coleman, 'Conspicuous consumption', p. 341.

91 Curthoys, Ann 1996, 'Visions, nightmares, dreams: women's history, 1975', AustralianHistorical Studies, vol. 27, no. 106, pp. 10-11.
} 


\section{Conclusion: Wollstonecraft's relevance today}

Wollstonecraft's influence extends well beyond the Anglophone world of feminist scholarship so far discussed here. In 2007, the Women's Studies Quarterly published a series of articles on Wollstonecraft's international reception, noting that her writings remain a key text for feminist activists and scholars around the world. One essay in the series, by Salma Maoulidi (executive director of the Sahiba Sisters Foundation, a women's development and advocacy network in Tanzania), sees Wollstonecraft's universal arguments as still relevant for women today. It is still important to seek 'the right to an education, the right to choose a spouse, the right to participation, and the right to a livelihood and to property' ${ }^{92}$ The idea that Wollstonecraft critiqued - that women require male protectionis still advocated by 'conservative forces in states such as Saudi Arabia and religious entities such as the Vatican' ${ }^{93}$ Maoulidi sees the most important part of Wollstonecraft's program as the demand for education - and a physical and moral environment conducive to learning. While she agrees that education is significant, she notes that the issue can be more complex, as women can be victims of repressive sexual politics and sexual harassment even on campus. The changes needed, she suggests, are not so much moral persuasion as institutional measures to prevent violations against women everywhere.

In the same issue, Dasa Duhacek in 'Mary Wollstonecraft in Serbia' also indicates her enduring importance, though in a very different context. ${ }^{94} \mathrm{~A}$ Vindication of the Rights of Woman, we learn, was first published in Serbian 200 years after its first appearance - in 1992, in the midst of the violent break-up of Yugoslavia. Publication had been planned in peacetime as part of a project to establish women's studies. By the time the translation appeared, however, the country was breaking apart. The task for feminists in the former Yugoslavia, Duhacek suggests, had been to oppose those who wanted to reintroduce a patriarchal society as part of their desire to renounce all the values of the despised socialist regime, including women's equality. The reason for publishing $A$ Vindication was originally to make the point that, in Duhacek's words, 'women's rights were not just a Marxist ruse, but a demand of modernity' $\cdot{ }^{95}$ Modernity in this context meant a subversion of traditional authority and a demand for educational reform, including the building of women's studies. The emphasis on education made Wollstonecraft highly relevant.

\footnotetext{
92 Maoulidi, Salma 2007, 'Mary Wollstonecraft: challenges of race and class in feminist discourse', Women's Studies Quarterly, vol. 35, nos 3-4 (Fall), pp. 280-6, quote on p. 281.

93 Ibid., p. 282.

94 Duhacek, Dasa 2007, 'Mary Wollstonecraft in Serbia', Women's Studies Quarterly, vol. 35, nos 3-4 (Fall), pp. $292-5$.

95 Ibid., p. 293.
} 
Mary Wollstonecraft continues to be mobilised in debates over the position of women in both East and West. On the occasion of the two hundred and fiftieth anniversary of Wollstonecraft's birth, legal scholar Helen Irving, for example, used Wollstonecraft to assert the triumph of the ideas of the Enlightenment in the West as contrasted with the lack of rights of women in Afghanistan and a general picture in the Third World of 'subordination, compounded by ignorance, lack of education, and poverty'. For these legacies of the Enlightenment, we should, she writes, 'give thanks to pioneers like Wollstonecraft' ${ }^{96}$ I think we should too, but the issues are far from simple. In formulations such as Irving's, we can see that whereas the idea of Eastern subordination of women was used by Wollstonecraft as a tool for demanding women's rights in Britain and the West, now those rights are assumed to be already won. Furthermore, there is the more serious problem that in the hands of anti-Muslim supporters of American militarism, the idea of Eastern subordination of women becomes an alibi for Western aggression and intervention. ${ }^{97}$ Suspicious of the assumptions of superiority and right embedded in these formulations, many Western feminists struggle to find a way to work together with non-Western feminists without participating in the use of feminism as a strategy for Western domination. Their struggle - so much more complex than those Western feminists faced or at least understood when rediscovering Wollstonecraft in the 1970s-reminds us that Wollstonecraft's legacy in the modern world is challenging indeed.

96 Irving, Helen 2009, 'Let women be enlightened', Sydney Morning Herald, 24 April 2009, viewed 29 March 2010, <http://www.smh.com.au/opinion/let-women-be-enlightened-20090423-agky.html?pag>

97 See Eisenstein, Hester 2009, Feminism Seduced: How global elites use women's labour and ideas to exploit the world, Paradigm Publishers, Boulder, Colo. 